\title{
The first record of a rare marine tardigrade, Halobiotus crispae Kristensen, 1982 (Eutardigrada: Hypsibiidae), from the Svalbard Archipelago
}

\author{
Jerzy Smykla $\cdot$ Lukasz Kaczmarek • \\ Katarzyna Huzarska $\cdot$ Lukasz Michalczyk
}

Received: 4 January 2011/Revised: 23 February 2011/Accepted: 24 February 2011/Published online: 23 March 2011

(C) The Author(s) 2011. This article is published with open access at Springerlink.com

\begin{abstract}
A rare marine tardigrade Halobiotus crispae Kristensen, 1982 was found abundant in intertidal flats at Josephbukta, Bellsund fiord, West Spitsbergen. This is the first record of this species from the Svalbard Archipelago. So far, the species has been found only in seven other localities in the northern hemisphere (between $56^{\circ}$ and $69^{\circ} \mathrm{N}$ ). The present record greatly extends the known geographical range to the north and also indicates a much wider distribution of the species than formerly reported. Moreover, a potential indicative character of this species
\end{abstract}

\section{J. Smykla $(\bowtie)$}

Department of Biodiversity, Institute of Nature Conservation,

Polish Academy of Sciences, Mickiewicza 33,

31-120 Kraków, Poland

e-mail: smykla@iop.krakow.pl

Present Address:

J. Smykla

Department of Biology and Marine Biology, University of North

Carolina Wilmington, $601 \mathrm{~S}$. College Rd,

Wilmington, NC 28403, USA

Ł. Kaczmarek

Department of Animal Taxonomy and Ecology, A. Mickiewicz

University, Umultowska 89, 61-614 Poznań, Poland

e-mail: kaczmar@amu.edu.pl

\section{K. Huzarska}

Department of Marine Ecology, Institute of Oceanology, Polish Academy of Sciences, Powstanców Warszawy 55, 81-712 Sopot, Poland

e-mail: huzar@iopan.gda.pl

\section{Ł. Michalczyk}

Centre for Ecology, Evolution and Conservation,

School of Biological Sciences, University of East Anglia,

Norwich NR4 7TJ, UK

e-mail: LM@tardigrada.net and of the study area in monitoring climatic changes is discussed.

Keywords Halobiotus crispae - Tardigrada .

New record $\cdot$ Spitsbergen $\cdot$ Intertidal flats Climate change

\section{Introduction}

Halobiotus crispae Kristensen, 1982 is a marine eutardigrade that belongs to the family Hypsibiidae. The species was originally described from Nipissat Bay, Disko Island, West Greenland by Kristensen (1982). During latter regular sampling for marine tardigrades around the world, it was also found in six additional localities in the northern hemisphere (Møbjerg et al. 2007; Fig. 1). The species occurs in intertidal and subtidal habitats to the depths of eight meters, where it dwells on filamentous algae that cover small stones and mussels or in silt and mud (Kristensen 1982; Eibye-Jacobsen 1997; Møbjerg et al. 2007). One of the important characteristics of this species is cyclomorphosis, i.e. the seasonal cyclic changes in morphology and physiology (Kristensen 1982; Møbjerg et al. 2007; Halberg et al. 2009a). Although the existence of cyclomorphosis has been suggested for other tardigrades, $H$. crispae remains the only tardigrade species for which cyclomorphosis has been recognised and described in detail (Møbjerg et al. 2007). Hence, H. crispae has often been sampled and used as a model organism in numerous studies of tardigrade biology, morphology and ultrastructure (Kristensen 1982; Møbjerg and Dahl 1996; EibyeJacobsen 1997, 2001; Møbjerg et al. 2007; Halberg et al. 2009a, b).

Intertidal and subtidal marine ecosystems are the most susceptible to climatic irregularities, ranging from 


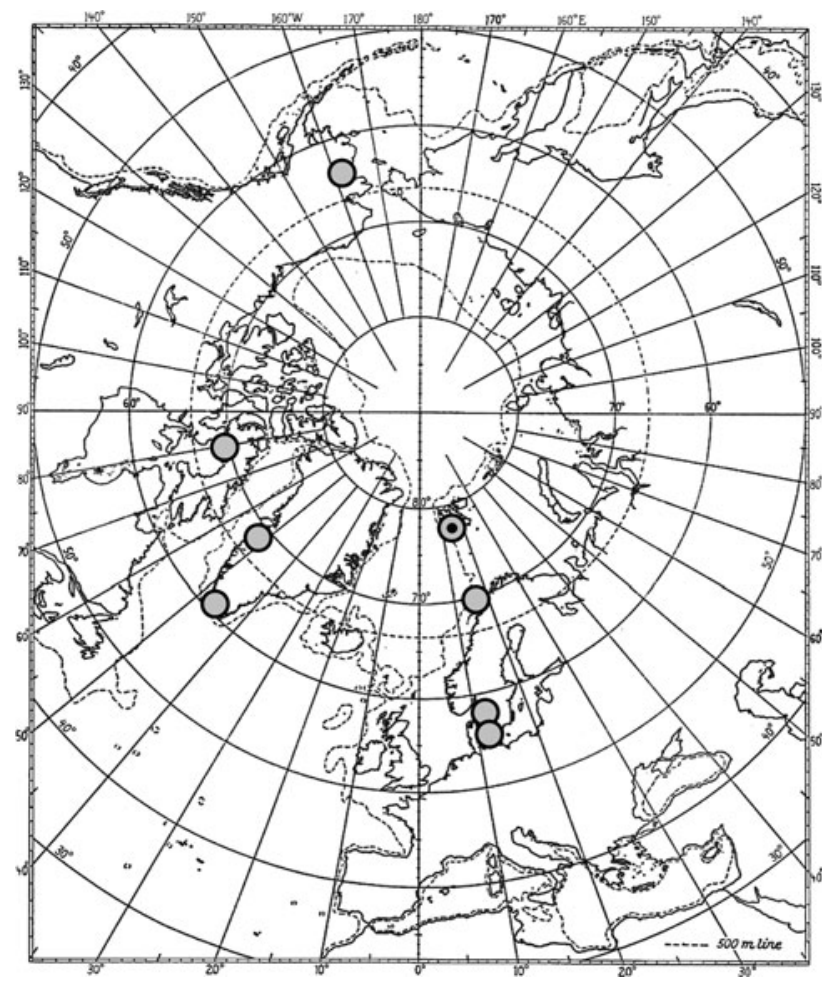

Fig. 1 Map with all known localities (including the present record, marked with a black dot in the centre) from which Halobiotus crispae was collected (after Møbjerg et al. 2007)

overheating, high UV radiation to drying, freezing, siltation and abrasion during low tides. Because of that, they can be used as models for studying the biological effects of climate changes (Węsławski et al. 2010). Due to the recent climatic changes and increased interest in biodiversity studies, a number of surveys were performed in intertidal and subtidal habitats around Svalbard. However, these studies focused mainly on macrofauna (see Węsławski et al. 1993, 2010 and cited literature therein) while largely ignoring meiofauna. Only very few studies (Szymelfenig et al. 1995; Węsławski et al. 1997; Włodarska-Kowalczuk et al. 1999; Veit-Köhler et al. 2008) examined meiofauna and reported tardigrades. Unfortunately, in these studies, tardigrades were considered only as a taxonomic group. In consequence, virtually nothing is known about marine tardigrades inhabiting coastal waters around Svalbard. For that reason, in summer 2010, during a survey of intertidal flats at Josephbukta (Bellsund fiord, Svalbard), several fine sediment samples were collected to investigate the tardigrade fauna of the region. In this note, we provide the first record of Halobiotus crispae from Svalbard (Arctic). This finding greatly extends the known geographic distribution of this model tardigrade species.

\section{Materials and methods}

Josephbukta $\left(77^{\circ} 31^{\prime} 50^{\prime \prime} \mathrm{N}, 14^{\circ} 37^{\prime} 50^{\prime \prime} \mathrm{E}\right)$ is a small bay located in the south branch of the Bellsund fiord, West Spitsbergen (Fig. 2). It consists of two distinct parts, the muddy intertidal flat and the main oval basin ca. $600 \mathrm{~m}$ in diameter, with a steep bottom and depths ranging from 2 to $50 \mathrm{~m}$. The intertidal flat is sheltered from the Bellsund fiord by a sandy-gravely spit formed by the marginal moraine of the Renardbreen Glacier. In the beginning of the twentieth century, which was also the end of the Little Ice Age, Josephbukta was completely covered by the Renardbreen Glacier. It became ice-free due to climatic changes and strong recession of the glacier in years 1936-60. Since then, this area was considerably affected by various morphogenetic factors, such as littoral, glacial, fluvioglacial and fluvial processes. The coastline and the bay were also strongly affected by marine processes, such as waving,
Fig. 2 Map of the investigation area: (a) Svalbard Archipelago (b) Bellsund Fiord, West Spitsbergen, (c) Josephbukta (based on maps from Norsk Polarinstitute, reprinted with permission)

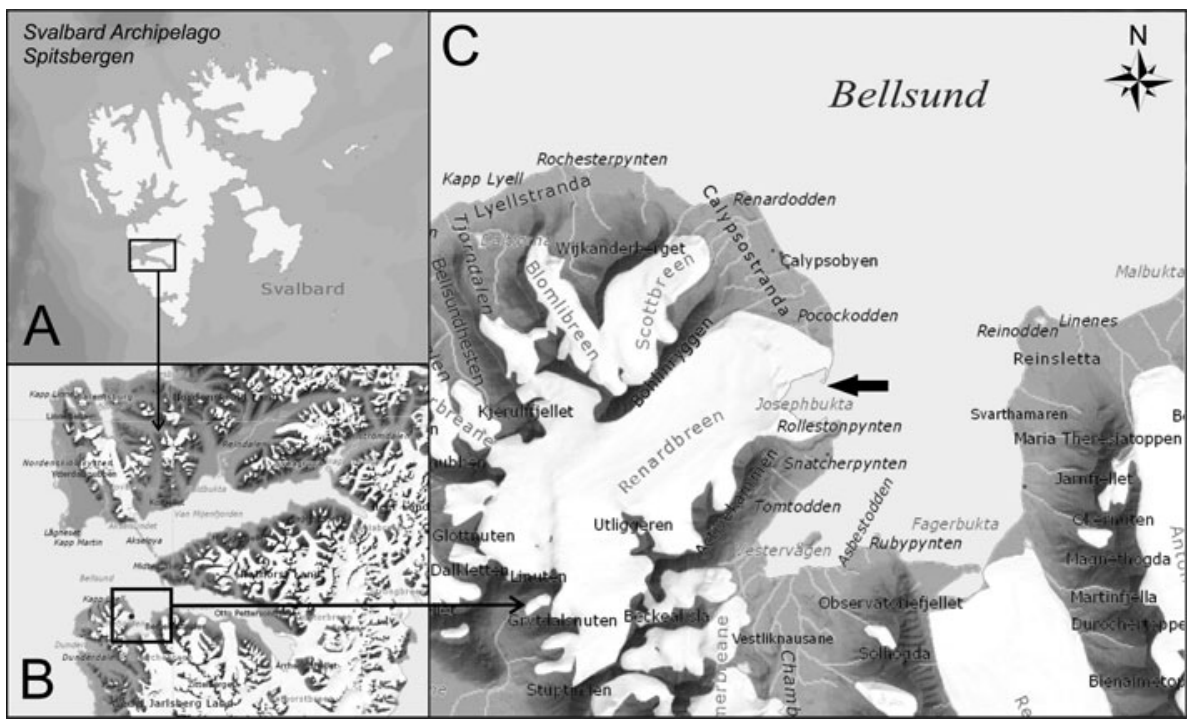


tides and long-shore currents. At present, due to a strong recession of the Renardbreen Glacier and due to disappearance of the fluvioglacial processes, the marine processes are now the major factors affecting costal environments of the Josephbukta area (Zagórski 2007 and cited literature therein).

During the summer of 2010, fine sediment samples from the Josephbukta intertidal flats were collected to investigate micro-biota of this environment. For tardigrade examination, ten fine sediment samples, $10 \mathrm{~cm}^{3}$ each, were collected. Sampling points were chosen approximately every $100 \mathrm{~m}$, on a profile running across the whole flat from the low to high tide water levels. Temperature and salinity of the upper layer of sediment were measured with electronic field reader. The recorded temperature was $5.1^{\circ} \mathrm{C}$, and salinity ranged between 22 and 23 PSU. The samples were collected on the 1 July 2010, during the low tide. The upper layer (down to $5 \mathrm{~mm}$ deep) of the exposed sediment surface was collected with a spatula and preserved immediately after collection in a $4 \%$ neutral formaldehyde solution. Then, the collected samples were shipped to Poland for analysis. In the laboratory, approximately $10 \%$ of each sample was processed for tardigrade extraction. Tardigrades were extracted under a stereomicroscope at $40 \times$ magnification and then mounted on microscope slides in Hoyer's medium. The slides were analysed under a phase contrast microscope (Olympus BX 51) associated with a digital camera. Animals and their traits were measured only if their orientations were suitable. The material is preserved in the collection of the second author at the Department of Animal Taxonomy and Ecology, A. Mickiewicz University, Poznań, Poland.

\section{Results and discussion}

The total of 268 specimens of Halobiotus crispae Kristensen, 1982 were extracted from the processed sediment samples. All the extracted specimens were in the active stage, which, among other things, is characterised by fully developed bucco-pharyngeal apparatus (Kristensen 1982; Møbjerg et al. 2007). No specimens in other cyclomorphic stages were found in the examined material. Currently, there are three species attributed to the genus Halobiotus (H. crispae Kristensen, 1982, H. arcturulius Crisp and Kristensen, 1983 and H. stenostomus (Richters, 1908)). All these species are extremely similar morphologically and therefore difficult to differentiate one from another. Moreover, they also occupy similar habitats in the northern hemisphere and their geographical distributions largely overlap. In the samples examined in this study, $H$. crispae was the only tardigrade species. The morphology (Figs. 3, 4, 5, 6) and measurements of all the examined specimens correspond well with the

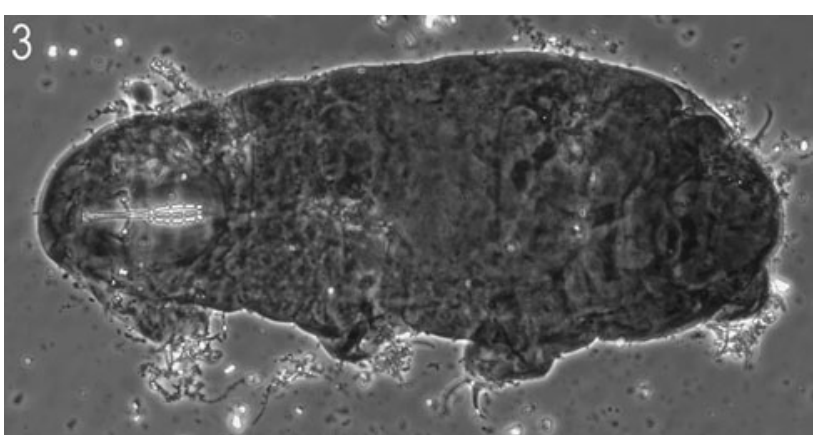

Fig. 3 Halobiotus crispae collected from Spitsbergen; habitus

original description of this species given by Kristensen (1982). Up to now only $H$. arcturulius was recorded from high Arctic localities (Crisp and Kristensen 1983; Mokievsky 1992). However, C. crispae is distinct from the latter species mainly in having a reticular sculpture on the dorsal side of the body.

Although the species is well known and has often been sampled (see Kristensen 1982; Møbjerg and Dahl 1996; Eibye-Jacobsen 1997, 2001; Møbjerg et al. 2007; Halberg et al. 2009a, b), the knowledge of its distribution seems to be only fragmentary. Since the discovery of an $\mathrm{H}$. crispae population at Nipissat Bay, Disko Island, West Greenland (Kristensen 1982), this species has been reported from only seven other localities in the northern hemisphere, all located between $56^{\circ}$ and $69^{\circ} \mathrm{N}$ (Møbjerg et al. 2007; Fig. 1). The present record from Svalbard at $77^{\circ} \mathrm{N}$ expands the range northward by a considerable extent.

The west coast of Svalbard is strongly influenced by warm waters of the West Spitsbergen Current (Berge et al. 2005). In consequence, it is characterised by ameliorated climatic conditions. In the intertidal flats along the West Spitsbergen coast, water temperature may reach over $10^{\circ} \mathrm{C}$, whereas temperature of waters along the east coast even during summer season is usually below $0^{\circ} \mathrm{C}$ (Węsławski et al. 1993). Such high temperatures make the conditions in intertidal flats located at the coast of West Spitsbergen similar to Subarctic waters. Literature data demonstrate that some littoral and shallow-water benthic fauna may be easily rafted from the south to the Svalbard archipelago (on kelps and floating litter) and a northward expansion of some species has been observed over the last decades (Węsławski et al. 1997; Berge et al. 2005; Węsławski et al. 2010). In its southern localities, H. crispae is often found in association with the blue mussel Mytilus edulis (Kristensen 1982; Eibye-Jacobsen 1997; Møbjerg et al. 2007). There is no information on occurrence of this thermophilous mollusc in Bellsund but its appearance, related to current climate warming, has been recently documented in the nearby Isfjord (Berge et al. 2005). It is therefore possible that the occurrence of $H$. crispae at such high latitude could result 
Figs. 4-6 Halobiotus crispae collected from Spitsbergen;

4 buccal apparatus, 5 external claw II, $\mathbf{6}$ cuticular thickening under external claw III
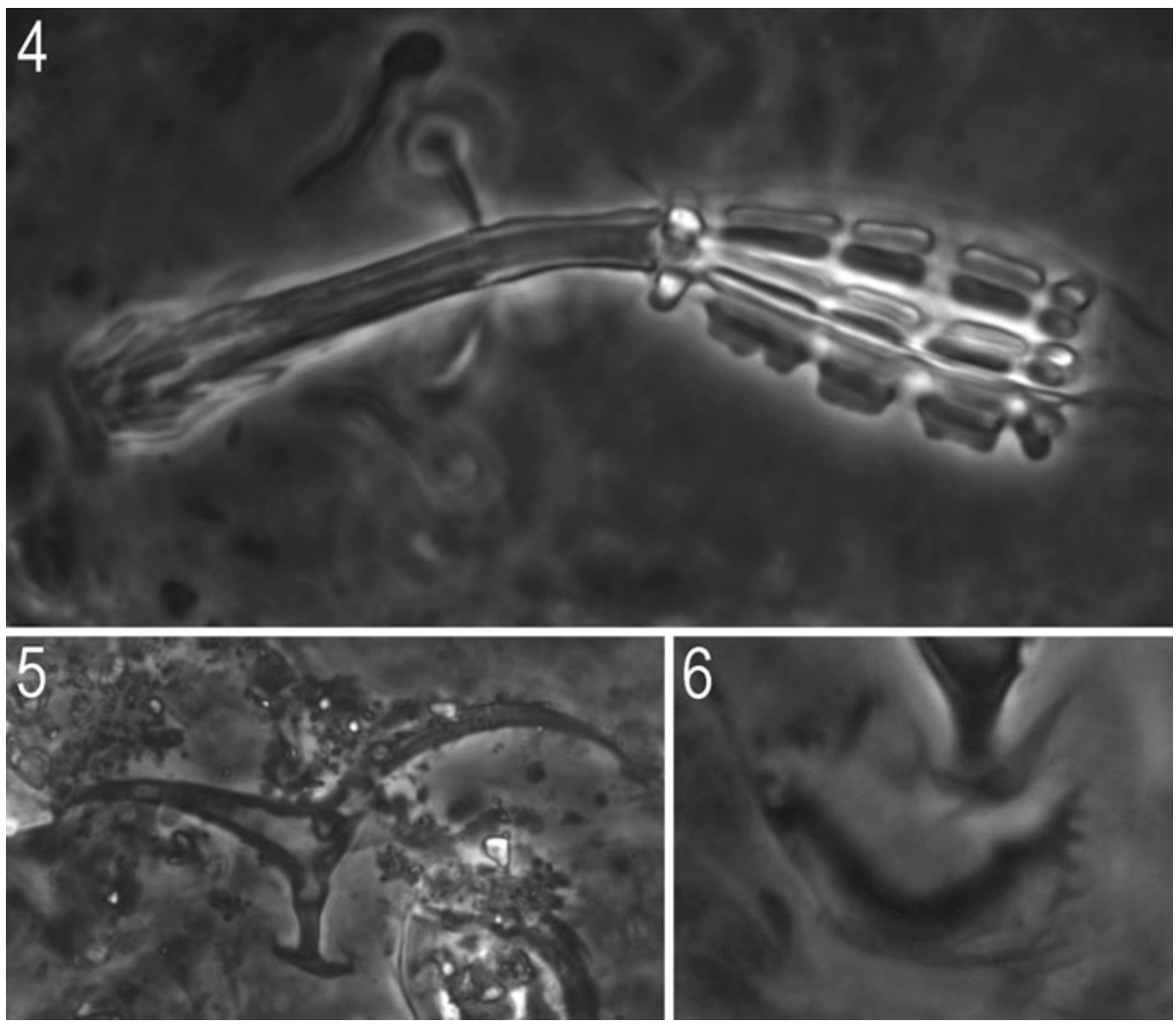

from more favourable climatic conditions of the investigated area and warm waters of the West Spitsbergen Current, which transported this tardigrade species from more southern localities.

In the previous surveys around the Svalbard archipelago, tardigrades were recorded only infrequently (in 2-7\% of samples) and in very low numbers, with the maximum abundance ranging 0.8-2.5 specimens per $10 \mathrm{~cm}^{2}$ (Szymelfenig et al. 1995; Węsławski et al. 1997; Włodarska-Kowalczuk et al. 1999; Veit-Köhler et al. 2008). Literature data indicate strong patchiness and variability in the Arctic intertidal meiofaunal abundance (e.g. Szymelfenig et al. 1995; Urban-Malinga et al. 2005). Therefore, due to the relatively low number and small volume of our samples, exact abundance of tardigrades for the locality surveyed in this study was not calculated. However, very high numbers of the extracted specimens and their presence in all examined samples indicate that their abundance can be even two orders of magnitude higher than the maximum densities reported for tardigrades from other localities around the Svalbard archipelago. In all these studies, tardigrade abundance was estimated from sediment samples collected to the depth of $3-5 \mathrm{~cm}$, whereas in our study, only the upper layer of sediments (to $5 \mathrm{~mm}$ deep) was collected. Mokievsky (1992), in his studies of Svalbard intertidal meiofauna, has shown that the first centimetre of sediment comprises $70-90 \%$ of all organisms and in case of some taxonomic groups even all specimens are found only to this shallow depth. Therefore, it is possible that the sampling design used by previous workers could contribute to the reported lower numbers. Investigations of the vertical distribution of tardigrades in marine sediments are needed to test this hypothesis.

It has been documented, however, that recent increases in the sea water temperature around Svalbard not only led to the expansion of new species but also significantly increased the abundance of zoobenthos (Węsławski et al. 2010). It is therefore likely that such exceptionally large quantities of $H$. crispae could be related to the favourable climatic conditions of the investigated locality. Accordingly, due to their ameliorated conditions, intertidal flats at Josephbukta potentially possess an indicative character and may thus be used as model ecosystems for predicting the biological effects of the climatic changes and warming of the Svalbard shores. To better understand the extent and nature of biodiversity changes related to the current climatic amelioration, re-examination of tardigrade specimens collected during previous studies and/or collection of new samples from around Svalbard to provide baseline data for this poorly investigated taxon is needed.

Acknowledgments The samples for this work were collected during the XXXIII Polar Expedition of the Polish Academy of Sciences to Svalbard in 2010. The authors would like to thank Piotr Wiśniewski 
for his help during the sampling and to the whole expedition team of the Polish Research Station "Horsund" for their hospitality and logistic support. The authors are also grateful to Sandra J. McInnes, Jan M. Węsławski, and an anonymous reviewer for their constructive comments on the manuscript. Thanks are also due to Jerzy Różański (the shipowner of $\mathrm{r} / \mathrm{v}$ "Eltanin") and the Department of Polar Research Institute of Geophysics of the Polish Academy of Sciences for providing logistical support during the fieldwork. The research was also partly supported by the Ministry of Science and Higher Education within the program Supporting International Mobility of Scientists III edition project no. 2 to JS and a grant no. NN304014939

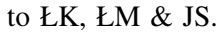

Open Access This article is distributed under the terms of the Creative Commons Attribution Noncommercial License which permits any noncommercial use, distribution, and reproduction in any medium, provided the original author(s) and source are credited.

\section{References}

Berge J, Johnsen G, Nilsen F, Gulliksen B, Slagstad D (2005) Ocean temperature oscillations enable reappearance of blue mussels Mytilus edulis in Svalbard after a 1000 year absencje. Mar Ecol Prog Ser 303:167-175

Crisp M, Kristensen RM (1983) A new marine interstitial eutardigrade from east Greenland, with comments on habitat and biology. Vidensk Meddr Dansk Naturh Foren 144:99-114

Eibye-Jacobsen J (1997) Development, ultrastructure and function of the pharynx of Halobidus crispae Kristensen, 1982 (Eutardigrada). Acta Zool 78:329-347

Eibye-Jacobsen J (2001) Are the supportive structures of the tardigrade pharynx homologous throughout the entire group? J Zool Syst Evol Res 39:1-11

Halberg KA, Persson D, Ramløv H, Westh P, Kristensen RM, Møbjerg N (2009a) Cyclomorphosis in Tardigrada: adaptation to environmental constraints. J Exp Biol 212:2803-2811

Halberg KA, Persson D, Møbjerg N, Wanninger A, Kristensen RM (2009b) Myoanatomy of the marine tardigrade Halobiotus crispae (Eutardigrada: Hypsibiidae). J Morphol 270:996-1013
Kristensen RM (1982) The first record of cyclomorphosis in Tardigrada based on a new genus and species from Arctic meiobenthos. Z Zool Syst Evol Forsch 20:249-270

Møbjerg N, Dahl N (1996) Studies on the morphology and ultrastructure of the Malpighian tubules of Halobiotus crispae Kristensen, 1982 (Eutardigrada). Zool J Linn Soc 116:85-99

Møbjerg N, Jørgensen A, Eibye-Jacobsen J, Halberg KA, Persson D, Kristensen RM (2007) New records on cyclomorphosis in the marine eutardigrade Halobiotus crispae (Eutardigrada: Hypsibiidae). J Limnol 66:132-140

Mokievsky VO (1992) Composition and distribution of intertidal meiofauna of Isfjorden, West Spitsbergen. Polish Polar Res $13: 31-40$

Szymelfenig M, Kwaśniewski S, Węsławski JM (1995) Intertidal zone of Svalbard. 2. Meiobenthos density and occurrence. Polar Biol 15:137-141

Urban-Malinga B, Wiktor J, Jabłońska A, Moens T (2005) Intertidal meiofauna of a high-latitude glacial Arctic fjord (Kongsfjorden, Svalbard) with emphasis on the structure of free-living nematode communities. Polar Biol 28:940-950

Veit-Köhler G, Laudien J, Knott J, Velez J, Sahade R (2008) Meiobenthic colonisation of soft sediments in arctic glacial Kongfjorden (Svalbard). J Exp Mar Biol Ecol 363:58-65

Węsławski JM, Wiktor J, Zajączkowski M, Swerpel S (1993) Intertidal zone of Svalbard. 1. Macroorganism distribution and biomass. Polar Biol 13:73-79

Węsławski JM, Zajączkowski M, Wiktor J, Szymelfenig M (1997) Intertidal zone of Svalbard. 3. Litoral of subarctic, oceanic island: Bjornoya. Polar Biol 18:45-52

Węsławski JM, Wiktor J Jr, Kotwicki L (2010) Increase in biodiversity in the arctic rocky litoral, Sorkappland, Svalbard, after 20 years of climate warming. Mar Biodivers 40:123-130

Włodarska-Kowalczuk M, Szymelfenig M, Kotwicki L (1999) Macro- and meiobenthic fauna of the Yoldiabukta glacial bay (Isfjorden, Spitsbergen). Polish Polar Res 20:367-386

Zagórski P (2007) The conditioning of the evolution of the NW part of the coast of Wedel Jarlsberg Land (Spitsbergen) during the last century. Landf Anal 5:102-106 